\title{
Parapharyngeal Lipomas: A Literature Review and Surgical Management
}

\section{Patrick Hesketh*, Shadaab Mumtaz and Deepak Komath}

Department of Oral and Maxillofacial Surgery, Royal Free London NHS Foundation Trust, London, United Kingdom

*Corresponding author: Patrick Hesketh, Department of Oral and Maxillofacial Surgery, Pond Street, London NW3 2QG, United Kingdom, Email: patrick.hesketh@.nhs.net

\section{Research Article}

Volume 5 Issue 1

Received Date: November 26, 2021

Published Date: December 28, 2021

DOI: $10.23880 /$ ijsst-16000162

\section{Abstract}

Parapharyngeal space is a potential deep neck space extending between skull base and the hyoid bone. It is considered to be a rare site for neoplasms and it is even unusual to see Lipomas presenting in this space. Due to the proximity to skull base and presence of important structures in this space, surgical intervention can be complicated. An extensive literature review was carried out to comprehend the presenting features and management of this rare entity. Thirty-six reports/series were included presenting 37 patients between 15-83 years of age with a peak in 5th decade having lipoma in the parapharyngeal space/skull base region. The dimensions of these benign entities ranged between $3 \mathrm{~cm}$ to $16 \mathrm{~cm}$. We present \& discuss our experience with a large lipoma traversing parotid, submandibular and parapharyngeal spaces and its surgical management. We hope that this review and surgical principles presented will be helpful to the trainees and surgeons dealing with these entities.

Keywords: Parapharyngeal Lipomas; Mesenchymal Tumour; Lipoma

\section{Introduction}

Lipoma is the most common mesenchymal tumour (16\%) in the body with about a quarter of these cases presenting in the head and neck region usually in the posterior neck [1]. Aetio-pathogenesis of this entity is unclear, however up to $80 \%$ of solitary lipomas were noted to have cytogenetic chromosomal alterations [2]. In patients presenting with recurrent or multiple lipomas, syndromic conditions such as Madelung disease, Dercum disease, Bannayan-Zonana syndrome, Familial multiple lipomatosis etc. should be excluded. The tissue itself consists of encapsulated adipocytes and connective tissue stroma. Some lipomas may present with atypical features such as thickened and increased septations with nodularity posing difficulties in diagnosis and surgical management [3]. Lipomas are seldom painful, and as such they often present with aesthetic concerns or compressive symptoms, at which time they are large indicating surgical intervention.

\section{The Parapharyngeal space}

The anatomical features of this complex inverted pyramidal space are presented below [4] (Figure 1):

\section{Boundaries}

Superior: Skull base

Inferior: Hyoid bone

Anterior: Pterygomandibular raphae

Posterior: Vertebral fascia

Lateral: Medial pterygoid muscle

Medial: Superior constrictor

The space is divided by the styloid process into the prestyloid and post-styloid compartments.

Pre-styloid contents:

Ascending pharyngeal artery

Deep lobe of parotid gland

Minor salivary glands

Fat

Post-styloid contents: 


\section{International Journal of Surgery \& Surgical Techniques}

- Carotid artery

- Internal jugular vein

- Cranial nerves IX to XII

- Cervical sympathetic chain.

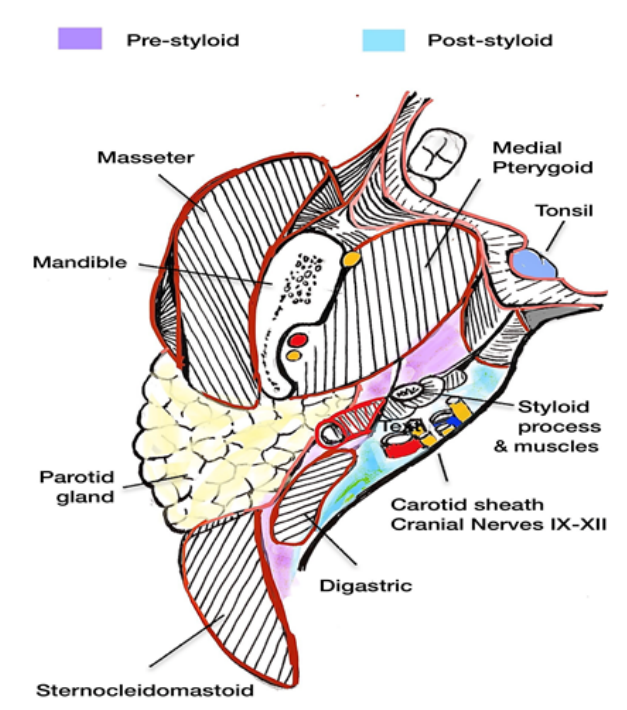

Figure 1: Anatomical representation of parapharyngeal space and its components (axial view).

\section{Literature Review}

A comprehensive English literature review was undertaken using PubMed, Medline and EMBASE databases using the term 'parapharyngeal lipoma' in both title and abstract between the periods of 1991-2021 (Figure 2). Literature without formal histological and/or cytological diagnosis was excluded to prevent ambiguity. Thirty-seven cases from 36 case reports and series (including the present case) were included in the review (Table 1).

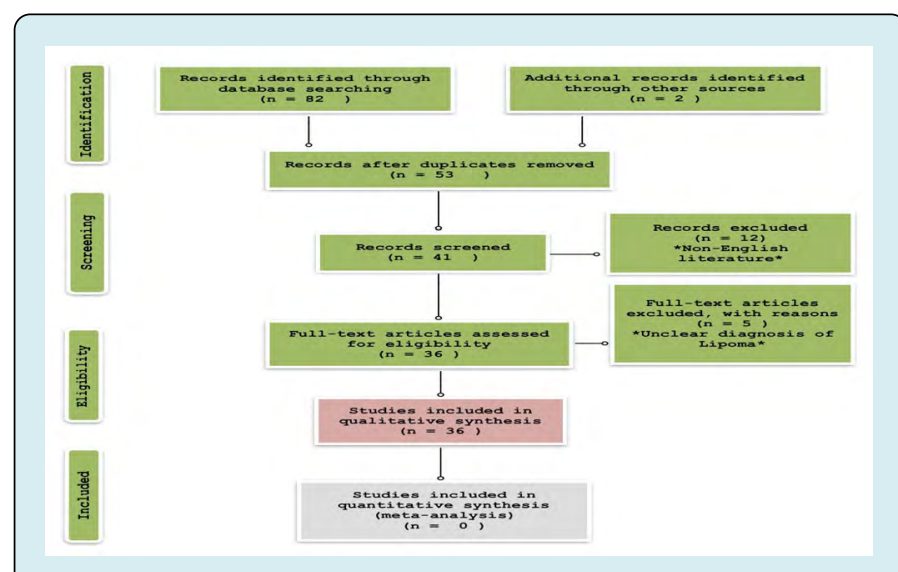

Figure 2: PRISMA flow diagram 2009 [5].

\begin{tabular}{|c|c|c|c|c|c|c|c|c|c|}
\hline No & Year & Author & Age & Sex & Laterality & $\begin{array}{c}\text { Dimensions } \\
\text { (cm) }\end{array}$ & Type & Management & $\begin{array}{c}\text { Recur } \\
\text { rence }\end{array}$ \\
\hline $\mathbf{1}$ & 2020 & Vijaykumar, et al. [6] & 15 & M & Left & $5 \times 4 \times 3$ & $\begin{array}{c}\text { Spindle cell } \\
\text { lipoma }\end{array}$ & Excision & No \\
\hline $\mathbf{2}$ & 2020 & Aslan, et al. [7] & 20 & M & Right & $6 \times 4.5$ & Simple lipoma & Transoral excision & - \\
\hline $\mathbf{3}$ & 2020 & Lee, et al. [8] & - & F & Left & $3 \times 4 \times 9.2$ & Simple lipoma & $\begin{array}{c}\text { Transcervical } \\
\text { excision }\end{array}$ & - \\
\hline $\mathbf{4}$ & 2020 & $\begin{array}{c}\text { Subramaniam. et } \\
\text { al. [9] }\end{array}$ & 54 & M & Right & $\begin{array}{c}9.5 \times 12.5 \times \\
8.5\end{array}$ & Sialolipoma & $\begin{array}{c}\text { Transcervical } \\
\text { excision }\end{array}$ & No \\
\hline $\mathbf{4}$ & 2019 & Imai, et al. [10] & 73 & F & Left & $9.5 \times 5$ & Simple lipoma & $\begin{array}{c}\text { Transcervical } \\
\text { excision }\end{array}$ & No \\
\hline $\mathbf{5}$ & 2019 & $\begin{array}{c}\text { Azandaryani, et al. } \\
{[11]}\end{array}$ & 47 & M & Left & $5.5 \times 4.5 \times 3.2$ & Simple lipoma & $\begin{array}{c}\text { Transcervical } \\
\text { excision }\end{array}$ & No \\
\hline $\mathbf{6}$ & 2019 & Marion, et al. [12] & 69 & M & Right & $\begin{array}{c}12.5 \times 10 \times \\
3.3\end{array}$ & Simple lipoma & $\begin{array}{c}\text { Transcervical } \\
\text { excision }\end{array}$ & - \\
\hline $\mathbf{7}$ & 2018 & Hakeem, et al. [13] & 50 & M & Left & 24 & Simple lipoma & $\begin{array}{c}\text { Transcervical } \\
\text { excision }\end{array}$ & No \\
\hline $\mathbf{8}$ & 2018 & Maglione, et al. [14] & 62 & F & Left & $5 \times 3.5 \times 2$ & Simple lipoma & Transoral robotic & No \\
\hline $\mathbf{9}$ & 2015 & Pal, et al. [15] & 40 & F & Right & $7 \times 5$ & Simple lipoma & $\begin{array}{c}\text { Transcervical } \\
\text { excision }\end{array}$ & No \\
\hline $\mathbf{1 0}$ & 2015 & $\begin{array}{c}\text { Garcia-Ortega, et al. } \\
{[16]}\end{array}$ & 48 & M & Right & $16 \times 12 \times 2.5$ & Simple lipoma & $\begin{array}{c}\text { Transcervical } \\
\text { excision }\end{array}$ & - \\
\hline
\end{tabular}




\section{International Journal of Surgery \& Surgical Techniques}

\begin{tabular}{|c|c|c|c|c|c|c|c|c|c|}
\hline 11 & 2015 & Aydin, et al. [17] & 68 & M & Right & - & Simple lipoma & $\begin{array}{c}\text { Transcervical } \\
\text { excision }\end{array}$ & - \\
\hline 12 & 2015 & Luczak, et al. [18] & 75 & M & Right & $\begin{array}{c}8.5 \times 5.8 \times \\
7.2\end{array}$ & Simple lipoma & $\begin{array}{c}\text { Transcervical } \\
\text { excision }\end{array}$ & No \\
\hline 13 & 2014 & Chen, et al. [19] & 45 & $\mathrm{M}$ & - & $6 \times 7$ & Simple lipoma & Transmandibular & No \\
\hline 14 & 2013 & Topak, et al. [20] & 17 & M & Left & $6 \times 5.5 \times 3$ & Angiomyxolipoma & $\begin{array}{c}\text { Transcervical/ } \\
\text { Tranparotid } \\
\text { excision }\end{array}$ & - \\
\hline 15 & 2013 & Chua, et al. [21] & 71 & $\mathrm{M}$ & Right & $9.4 \times 6.7$ & Simple lipoma & Transoral excision & - \\
\hline 16 & 2012 & Casale, et al. [22] & 70 & $\mathrm{M}$ & Left & $9 \times 6$ & Simple lipoma & $\begin{array}{c}\text { Transcervical } \\
\text { excision }\end{array}$ & - \\
\hline 17 & 2012 & Bulkele, et al. [23] & 68 & $\mathrm{M}$ & Left & $4 \times 1.5 \times 1$ & Osteolipoma & Transoral excision & - \\
\hline 18 & 2012 & Presutti, et al. [24] & 61 & $\mathrm{~F}$ & - & $3 \times 1.5 \times 1.8$ & Simple lipoma & $\begin{array}{c}\text { Transcervical } \\
\text { excision }\end{array}$ & - \\
\hline 19 & 2011 & Crowso, et al. [25] & 83 & $\mathrm{M}$ & Left & - & Simple lipoma & Monitoring & - \\
\hline 20 & 2011 & Crowso, et al. [25] & 55 & $\mathrm{M}$ & Left & 13.6 & Simple lipoma & $\begin{array}{c}\text { Transcervical } \\
\text { excision }\end{array}$ & - \\
\hline 21 & 2011 & Bohm, et al. [26] & 15 & $\mathrm{~F}$ & Left & $3.8 \times 3.5 \times 2.8$ & Osteolipoma & Transoral excision & No \\
\hline 22 & 2009 & Derin, et al. [27] & 44 & $\mathrm{M}$ & Right & $5.5 \times 7 \times 2.5$ & Simple lipoma & Transparotid & No \\
\hline 23 & 2009 & Kim, et al. [28] & 75 & $\mathrm{~F}$ & Right & $8 \times 8$ & Simple lipoma & Transparotid & No \\
\hline 24 & 2006 & McNeill, et al. [29] & 75 & $\mathrm{M}$ & Left & $6 \times 3$ & Simple lipoma & Monitoring & - \\
\hline 25 & 2006 & Chen, et al. [30] & 59 & $\mathrm{M}$ & Left & $4 \times 2$ & Simple lipoma & - & - \\
\hline 26 & 2004 & Erkan, et al. [31] & 71 & $\mathrm{~F}$ & Right & $\begin{array}{c}5.5 \times 4.5 \times \\
3.5 \\
\end{array}$ & Simple lipoma & $\begin{array}{c}\text { Transcervical } \\
\text { excision }\end{array}$ & - \\
\hline 27 & 2004 & Ulku, et al. [32] & 18 & M & Right & - & Simple lipoma & $\begin{array}{c}\text { Transcervical } \\
\text { excision }\end{array}$ & No \\
\hline 28 & 2004 & Singh, et al. [33] & 38 & $\mathrm{~F}$ & Right & - & Simple lipoma & $\begin{array}{c}\text { Transcervical } \\
\text { excision }\end{array}$ & No \\
\hline 29 & 2003 & Pelland, et al. [34] & 53 & $\mathrm{M}$ & Right & $9 \times 4 \times 5$ & Simple lipoma & - & - \\
\hline 30 & 2002 & Smith, et al. [35] & 49 & M & Left & - & Simple lipoma & $\begin{array}{c}\text { Transcervical } \\
\text { excision }\end{array}$ & No \\
\hline 31 & 2001 & Baumann, et al. [36] & 45 & $\mathrm{M}$ & Right & $7.5 \times 3 \times 6$ & $\begin{array}{l}\text { Spindle cell } \\
\text { lipoma }\end{array}$ & Transparotid & No \\
\hline 32 & 2001 & Hazarika, et al. [37] & 17 & $\mathrm{~F}$ & Right & $5 \times 4$ & Osteolipoma & $\begin{array}{c}\text { Transcervical } \\
\text { excision }\end{array}$ & No \\
\hline 33 & 1999 & Scott, et al. [38] & 69 & M & Right & $\begin{array}{c}16 \times 4.5 \times \\
1.5\end{array}$ & Simple lipoma & $\begin{array}{c}\text { Transcervical } \\
\text { excision }\end{array}$ & - \\
\hline 35 & 1995 & Elanga, et al. [39] & 55 & $\mathrm{~F}$ & Right & $4.5 \times 3.5 \times 1$ & Simple lipoma & - & No \\
\hline 35 & 1994 & Eckel, et al. [40] & 54 & $\mathrm{M}$ & Right & $3 \mathrm{~cm}$ & Simple lipoma & Laser excision & - \\
\hline 36 & 1992 & Higashi, et al. [41] & 61 & $\mathrm{M}$ & Right & $9 \times 7.5 \times 3.5$ & Simple lipoma & - & - \\
\hline 37 & 2020 & Present case & 52 & M & Left & $9 \times 6 \times 2.5$ & Simple Lipoma & $\begin{array}{c}\text { Transparotid/ } \\
\text { Submandibular }\end{array}$ & No \\
\hline
\end{tabular}

Table1: Literature review of parapharyngeal lipoma

Majority of the patients were males (71\%) with average age of 52.46 years (Median 54 years). The smallest size reported was $3 \mathrm{~cm}$ and the largest was $9.5 \times 12.5 \times 8.5 \mathrm{~cm}$ in maximum dimensions. Eighty-two percent of patients were histologically and/or cytologically diagnosed as having a simple lipoma. The other subtypes noted were spindle cell 


\section{International Journal of Surgery \& Surgical Techniques}

lipoma, osteolipoma, angiomyxolipoma and sialolipoma. Half of the patients underwent transcervical excision (54\%) and with transparotid, transoral \& submandibular access being the other approaches used. A single patient was operated with Transoral robotic surgery for a lipoma of $5 \times 3.5 \times 2 \mathrm{~cm}$ maximum size [14].

\section{Case Presentation}

A 52 year old Nigerian gentleman presented with a progressively growing left neck mass since 18 months. He denied any odynophagia, dysphagia, dysphonia, weight loss or night sweats. His past medical history was significant for well-controlled diabetes mellitus for which he was on Metformin. He was a non-smoker and denied regular alcohol intake. Examination revealed a large swelling of the left sided parotid and submandibular region with smooth \& nonerythematous overlying skin. All cranial nerves appeared intact. Intraoral examination noted fullness of the left parapharyngeal region. Magnetic resonance imaging (MRI) revealed a $9 \times 6 \times 2.5 \mathrm{~cm}$ homogeneous hyperintense mass involving left parotid, submandibular and parapharyngeal region abutting the base of skull (Figure 3). No other atypical features were noted.

The patient underwent excision with transparotid/ submandibular approach and the histological evaluation diagnosed it as simple lipoma.

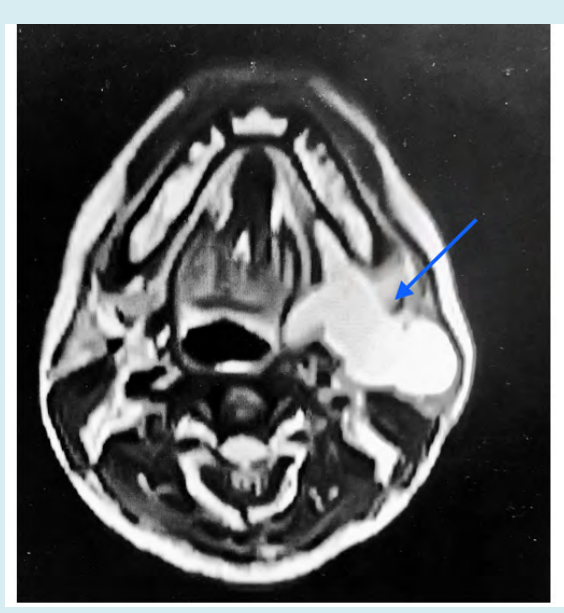

Figure 3: Axial MR image showing a large lipoma involving parotid, submandibular and parapharyngeal spaces.

\section{Surgical Technique}

Under general anaesthetic, a modified Blair incision with submandibular extension was made. Blunt and sharp subplatysmal dissection was undertaken. Facial nerve was carefully isolated and preserved with additional intraoperative monitoring (Medtronic ${ }^{\mathrm{TM}}$ nerve integrity monitor).
The submandibular gland was isolated and pushed medially to dissect part of the lipoma. The rest of the horse-shoe shaped lipomatous tissue was noted to extend to the parotid region with extension into the retromandibular region going towards the skull base. This was carefully excised with blunt meticulous surgical dissection (Figure 4). No intra-oral access was required. Two drains (Size 12 Redivac $^{\mathrm{TM}}$ ) were inserted in parotid and submandibular region for 48 hours.

No immediate complications were noted in the postoperative period. Very minimal weakness of left marginal mandibular nerve was noted which improved after a few weeks (Figure 5). The patient was discharged with appropriate wound care instructions. No recurrence has been noted on 3 months follow-up.

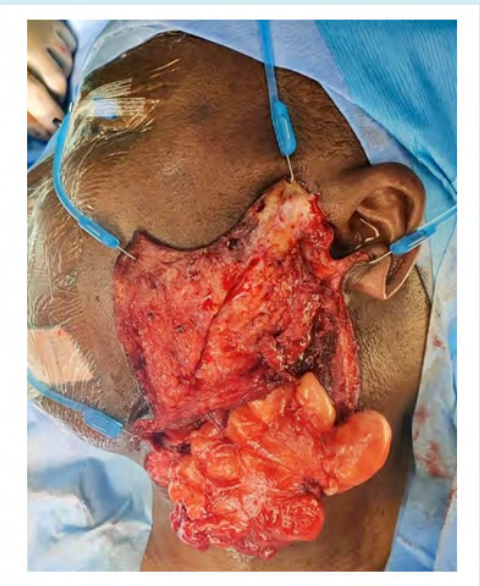

Figure 4: Surgical excision of the lipoma via Transparotid/ Submandibular approach.

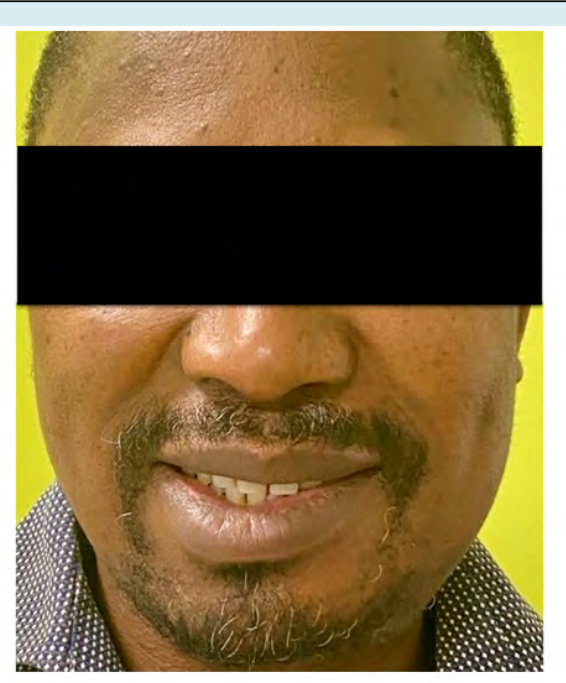

Figure 5: Two-weeks follow-up of the patient showing mild left marginal mandibular nerve weakness. 


\section{International Journal of Surgery \& Surgical Techniques}

\section{Discussion}

Lipomas are the most common soft tissue neoplasms, with an estimated incidence of 2.1 per 100 individuals. They are most commonly seen in the 5th-7th decades of life, and show a general predisposition to the male gender [42]. Despite this, lipomas of the parapharyngeal space (PPS) are a rare entity with only 36 cases being reported in published in the reviewed literature in the past 20 years prior to the case presented. PPS tumours as a subcategory are rare, comprising only $0.5 \%$ of head and neck tumours [32]. In the pre-styloid compartment, the tumours are mainly salivary in nature and those of the post-styloid region are commonly neurogenic [43].

PPS lipomas are thought to comprise just 1-2\% of all PPS tumours. As slow growing tumours, lipomas in this area tend not to present with symptoms until large, as can be seen in the sizes of the reported cases. Presentation is often due to aesthetic or compressive symptoms due to the size of the lump in the neck and very occasionally picked up incidentally by the dentist and/or surgeons during routine examination. This may occur if the tumour grows medially, where it can bulge and push out the superior constrictor muscle. This would be seen clinically in the oropharynx as an asymmetrical swelling of the affected side [15]. Presentation with pain, or symptoms of cranial nerve deficits, such as hoarseness and tongue deviation, are more suggestive of malignant disease.

There are many histological subtypes of lipomas (Table 2). The most common subtype seen in the reported cases of PPS lipomas is simple/conventional lipoma $(n=31)$, followed by osteolipoma, spindle cell lipoma and angiomyxolipoma.

\begin{tabular}{|c|c|}
\hline Type & Tissue \\
\hline Simple/Conventional & Encapsulated adipose tissue \\
\hline Adenolipoma & Adipose tissue with entrapped eccrine glands/ducts \\
\hline Angiolipoma & Adipose tissue with blood vessels \\
\hline Myelolipoma & Adipose tissue and haematopoietic tissue \\
\hline Fibrolipoma & Adipose tisse with fibrous connective tissue \\
\hline Myolipoma & Adipose tissue with smooth muscle cells \\
\hline Chondrolipoma & Adipose tissue and chondrocytes \\
\hline Osteolipoma & Adipose tissue with lamellar bone \\
\hline Myxolipoma & Adipose tissue with mucoid component \\
\hline Sclerotic lipoma & Adipose tissue with sclerotic collagen \\
\hline Sialolipoma & Adipose tissue with salivary gland elements \\
\hline Pleomorphic/Spindle cell lipoma & Adipose tissue with spindle cell and pleomorphic giant cells \\
\hline
\end{tabular}

Table 2: Lipoma Subtypes.

Diagnosis of PPS lipomas may be reliably predicted through Magnetic resonance imaging (MRI) giving a homogenous signal which is isointense when compared to subcutaneous fat [44]. This differentiates the mass from liposarcomas which may vary from having thick septations, local invasion or even show complete sarcomatous change [42]. However, surgeons should consider getting cytological or histological diagnosis to rule out low-grade liposarcomas which may have similar features compared to the benign variant. Asymptomatic lipomas can be safely monitored as there is no evidence of malignant transformation [42]. Additionally, surgical excision has to be weighed against risk of damaging important neuro-vascular structures of the PPS.

A number of common surgical approaches have been reported to access PPS tumours. The most common are transcervical, transmandibular, transoral, transparotid and preauricular \& infratemporal or a combination of multiple approaches [15]. More recently, robotic surgical aids have been combined with a transoral approach [14]. In our literature review, transcervical access was the most common $(n=13)$ due to wide exposure it provides allowing for good access \& control of vital neurovascular structures. Larger tumours $(>8 \mathrm{~cm})$ may require a combination of approaches for safe and adequate access.

Recurrence of a lipoma anywhere in the body is thought to be around 4-5\%. This is thought to be higher in deeper or infiltrative lipomas [45]. As PPS tumours are deeper, and often close to vital structures, meaning they might not be able to be excised completely, the presumption would be that local recurrence rates would be higher for PPS lipomas 


\section{International Journal of Surgery \& Surgical Techniques}

which however is not proven in our substantial review.

We have presented a detailed outlook of parapharyngeal space lipomas supplemented with largest review of literature pertaining to this subject available till now. It is hoped that this review will give more insight to the surgical trainees and surgeons in the field of otolaryngology and maxillofacial surgery.

\section{Declarations}

Conflict of Interests - none

Funding - none

Ethical approval - n/a

\section{References}

1. Razek AA, Huang BY (2011) Soft tissue tumors of the head and neck: imaging-based review of the WHO classification. Radiographics 31(7): 1923-1954.

2. Bartuma H, Hallor KH, Panagopoulos I, Collin A, Rydholm A, et al. (2007) Assessment of the clinical and molecular impact of different cytogenetic subgroups in a series of 272 lipomas with abnormal karyotype. Genes Chromosomes Cancer 46(6): 594-606.

3. Bancroft LW, Kransdorf MJ, Peterson JJ, O'Connor MI (2006) Benign fatty tumors: classification, clinical course, imaging appearance, and treatment. Skeletal Radiol 35(10): 719-733.

4. Day T, Albergotti G (2021) Neoplasms of the Neck, Cummings Otolaryngology: Head and Neck Surgery $\left(7^{\text {th }}\right.$ edn.), pp: 1764.

5. Moher D, Liberati A, Tetzlaff J, Altman DG, The PRISMA Group (2009) Preferred Reporting Items for Systematic Reviews and Meta-Analyses: The PRISMA Statement. PLoS Med 6(7): e100009.

6. Vijayakumar G, Kamboj M, Narwal A, Devi A, Singh $V$ (2020) Bucco-Parapharyngeal Occurrence of Pleomorphic Spindle Cell Lipoma-A Unique Entity: Case Report. J Clin Pediatr Dent 44(2): 107-111.

7. Aslan M, Ozturk EO, Dogukan FM (2020) A Rare Cause of Dysphagia: Giant Lipoma in Parapharyngeal Space. J Craniofac Surg 31(7): e667-e668.

8. Lee HSH, Ngai CM (2020) Parapharyngeal space lipoma: a case report. Hong Kong Med J 26(5):438-440.

9. Subramaniam S, Johan S, Hayati F, Ng CY, Azizan N, et al. (2020) Giant submandibular sialolipoma masquerading as huge goitre: a case report. BMC Surg 20(1): 130.
10. Imai $T$, Nakazawa M, Uzawa N (2019) Lipoma Rarely Involving Multiple Suprahyoid Fascial Spaces: A Large Lesion Removed With Bimanual Transcervical Finger Dissection Using a "Push-Pull Down" Maneuver. J Craniofac Surg 30(8): e717-e719.

11. Azandaryani AR, Eftekharian M, Taghipour M (2019) Large Laryngeal Lipoma with Extra Laryngeal Component Mimics Mixed Form Laryngocele: A Case Report. Adv J Emerg Med 3(4): e45.

12. Marion F, Videlaine A, Piot B, Merlet FL, Longis J, et al. (2019) A giant parapharyngeal lipoma causing obstructive sleep apnea. J Stomatol Oral Maxillofac Surg 120(6): 595-597.

13. Hakeem AH, Hakeem IH, Budharapu A, Wani FJ (2018) Giant Parapharyngeal Space Lipoma Extending to the Pterygoid Region (Anterior Skull Base). J Craniofac Surg 29(2): e149-e150.

14. Maglione MG, Guida A, Pavone E, Longo F, Aversa C, et al. (2018) Transoral robotic surgery of parapharyngeal space tumours: a series of four cases. Int J Oral Maxillofac Surg 47(8): 971-975.

15. Pooja P, Bikramjit S, Arvinder S (2015) Unusual parapharyngeal lipoma. Indian J Otolaryngol Head Neck Surg 67(Suppl 1):158-160.

16. Ortega DYG, Pedraza AG, Ortiz KL (2015) Parapharyngeal space lipomatosis with secondary dyspnea, disphagia and disphonia. Int J Surg Case Rep15: 54-56.

17. Aydin O, Erdogan S, Derin S (2015) Parapharyngeal Space Lipoma. J Craniofac Surg 26(7): e658-659.

18. Luczak K, Dorobisz K, Krecicki T, Janczak D, Chabowski M, et al. (2015) The Lipomatosis of the Parapharyngeal and Retropharyngeal Space: A Case Report. Srp Arh Celok Lek 143(7-8): 455-457.

19. Chen WL, Wang WJ, Huang ZQ, Zhang DM (2014) Osteotomy in the vertical ramus outside the mandibular foramen for tumours in the parapharyngeal space. J Craniomaxillofac Surg 42(3): e29-32.

20. Topak M, Develioglu ON, Celebi S, Caglar E, Kimiloglu E, et al. (2013) A rare tumor of the parapharyngeal space: angiomyxolipoma. J Craniofac Surg 24(5): 1724-1725.

21. Chua DYK, Lim MY, Teo DTW, Hwang SY (2013) Retropharyngeal lipoma with parapharyngeal extension: is transoral excision possible? Singapore Med J 54(9): e176-e178.

22. Casale M, Salvinelli F, Mallio CA, Frari V, Vincenzi B, et 


\section{International Journal of Surgery \& Surgical Techniques}

al. (2012) Upper airway study should always come before any sleep study in OSAS evaluation: a giant parapharyngeal lipoma behind OSAS. Eur Rev Med Pharmacol Sci 16 (Suppl 4): 106-109.

23. Bulkeley W, Mills OL, Gonzalvo A, Wong K (2012) Osteolipoma of the parapharyngeal space mimicking liposarcoma: a case report. Head Neck 34(2): 301-303.

24. Presutti L, Molteni G, Malvè L, Marchioni D, Ghidini A, et al. (2012) Parapharyngeal space tumors without mandibulotomy: our experience. Eur Arch Otorhinolaryngol 269(1): 265-273.

25. Crowson MG, Hoang J, Esclamado RM (2016) Rare cases of large parapharyngeal lipomas. Am J Otolaryngol 37(1): 54-58.

26. Bohm KC, Birman MV, Silva SR, Lesperance MM, Marentette LJ, et al. (2011) Ossifying lipoma of c1-c2 in an adolescent. J Pediatr Orthop 31(5): e53-e56.

27. Derin AT, Güney K, Turhan M, Ağirdir BV (2009) Parapharyngeal lipoma: a case report. Kulak Burun Bogaz Ihtis Derg 19(2): 95-98.

28. Kim DS, Kwon H, You G, Jung SN (2009) Surgical treatment of a giant lipoma in the parotid gland. J Craniofac Surg 20(5): 1601-1602.

29. McNeill EJ, Samuel PR, England S (2006) Lipoma of the parapharyngeal space. J Laryngol Otol 120(2): e9.

30. Chen KTK (2006) Fine-needle aspiration of parapharyngeal lipoma. Diagn Cytopathol 34(1): 82-83.

31. Erkan AN, Yavuz H, Yllmazer C, Özlüoğlu L, Bolat FA (2004) Radiology Quiz Case 2. Arch Otolaryngol Head Neck Surg 130(8): 997.

32. Ulku CH, Uyar Y (2004) Parapharyngeal lipoma extending to skull base: a case report and review of the literature. Skull Base 14(2): 121-125.

33. Singh PP, Sharma A, Gupta N (2004) Parapharyngeal space lipoma. Indian J Otolaryngol Head Neck Surg 56(2): 152-154.

34. Pellanda A, Zagury S, Pasche P (2003) Parapharyngeal lipoma causing obstructive sleep apnea syndrome. Otolaryngol Head Neck Surg 128(2): 301-302.

35. Smith JC, Snyderman CH, Kassam AB, Fukui MB (2002) Giant parapharyngeal space lipoma: case report and surgical approach. Skull Base 12(4): 215-220.

36. Baumann I, Dammann F, Horny HP, Plinkert PK (2001) Spindle cell lipoma of the parapharyngeal space: first report of a case. Ear Nose Throat J 80(4): 244, 247-50.

37. Hazarika P, Pujary K, Kundaje HG, Rao PL (2001) Osteolipoma of the skull base. J Laryngol Otol 115(2): 136-139.

38. Scott RF, Collins MM, Wilson JA (1999) Parapharyngeal lipoma. J Laryngol Otol 113(10): 935-397.

39. Elango S (1995) Parapharyngeal space lipoma. Ear Nose Throat J 74(1): 52-53.

40. Eckel HE, Jungehülsing $M$ (1994) Lipoma of the hypopharynx: pre-operative diagnosis and transoral resection. J Laryngol Otol 108(2): 174-177.

41. Higashi K, Sarashina N, Okamoto T, Matsuki C, Heim S (1992) Supernumerary ring marker chromosome as a secondary rearrangement in a parapharyngeal lipoma with $\mathrm{t}(10 ; 12)(\mathrm{q} 25 ; \mathrm{q} 15)$ as the primary karyotypic abnormality. Cancer Genet Cytogenet 64(2): 163-165.

42. Murphey MD, Carroll JF, Flemming DJ, Pope TL, Gannon FH, et al. (2004) From the archives of the AFIP: benign musculoskeletal lipomatous lesions. Radiographics 24(5): 1433-1466.

43. Ijichi K, Murakami S (2017) Surgical treatment of parapharyngeal space tumors: A report of 29 cases Oncol Lett 14(3): 3249-3254.

44. Miller FR, Wanamaker JR, Lavertu P, Wood BG (1996) Magnetic resonance imaging and the management of parapharyngeal space tumors. Head Neck 18(1): 67-77.

45. Johnson CN, Ha AS, Chen E, Davidson D (2018) Lipomatous Soft-tissue Tumors. J Am Acad Orthop Surg 26(22): 779-788. 